\title{
A Stakeholder Analysis of the klia2 Airport Terminal Project
}

\author{
Nor Azlina Mohd Isa ${ }^{1 *}$, Norlida Abdul Hamid², Tan Peck Leong ${ }^{3}$ \\ ${ }^{1,2,3}$ Arshad Ayub Graduate Business School, Universiti Teknologi MARA, 40450 Shah Alam, Malaysia
}

\begin{abstract}
Managing an airport terminal project is complex, due to a large number of stakeholders involved. Airport stakeholders include many organisations and individuals, making it a collaborative service environment. Stakeholder theory denotes that organisation should strive to create value for all its stakeholders without the need to trade off. The purpose of this study is to identify the respondents to measure the collective perspectives of the klia2 airport terminal project. This is an overview of the literature relating to the stakeholder theory and identification of the stakeholders for an airport terminal project in general and specifically for the klia2 terminal.
\end{abstract}

(c) 2016. The Authors. Published for AMER ABRA by e-International Publishing House, Ltd., UK. This is an open access article under the CC BY-NC-ND license (http://creativecommons.org/licenses/by-nc-nd/4.0/).

Peer-review under responsibility of AMER (Association of Malaysian Environment-Behaviour Researchers), ABRA (Association of Behavioural Researchers on Asians) and CE-Bs (Centre for Environment-Behaviour Studies), Faculty of Architecture, Planning \& Surveying, Universiti Teknologi MARA, Malaysia.

Keywords: Stakeholder theory; Airport stakeholders; Airport terminal; Project management

\section{Introduction}

The recently developed airport terminal has evolved from merely functioning as a terminal for aviation related travel activities to a multimodal transportation hub and has become a terminal housed with commercial and hospitality services in addition to basic air travel related services. An airport terminal project, in particular for a major airport of a country, has always been treated as the nation's project and most of the time is an iconic architectural statement, since it is the main gateway to the country. Managing large-scale construction projects has been known to come with many challenges (Toor \& Ogunlana, 2009). Complexity is added to the equation for an airport development project as it involves multiple stakeholders with different goals and objectives (Schaar \& Sherry, 2010). Furthermore, airport stakeholders come in the forms of various organisations as well as many individuals. Stakeholders' involvements in any airport development project are inevitable (Harrison et al., 2012, Schaar \& Sherry, 2010). An airport terminal accommodates many stakeholders who operate, reside or use the terminal as passengers as well as other users.

\footnotetext{
* Corresponding author. Tel.: +603-8777 7000

E-mail address: azlina.isa@gmail.com
}

2398-4287 @ 2016. The Authors. Published for AMER ABRA by e-International Publishing House, Ltd., UK. This is an open access article under the CC BY-NC-ND license (http://creativecommons.org/licenses/by-nc-nd/4.0/).

Peer-review under responsibility of AMER (Association of Malaysian Environment-Behaviour Researchers), ABRA (Association of Behavioural Researchers on Asians) and cE-Bs (Centre for Environment-Behaviour Studies), Faculty of Architecture, Planning \& Surveying, Universiti Teknologi MARA, Malaysia.

DOI: http://dx.doi.org/10.21834/e-bpj.v1i3.372 
The contradicting needs of various stakeholders impose an enormous challenge for the project owner especially in the decision-making process from the project inception to implementation stages, to determine the requirements that create value for all stakeholders. Studies suggested that identification and engagement of interested parties in the early phase of construction, and proper management of stakeholders will help to increase the acceptance of the project by public (Sözüern\& Spang, 2014) and enhance the project outcome (Fageha \& Aibinu, 2013).

From the airport operator and project owner perspectives, apart from the right sizing and design capacity, it is fairly vital for an airport terminal to take into consideration all stakeholders' requirements during the planning, design and execution stages, for the terminal to fit its intended operational function. However, there is a limit to adhering to various stakeholders' requests as some of the requirements may conflict with the design intent and the concept of operations of the terminal building and the business objectives of the owner of the project. Furthermore, the process to capture end user requirements are also complex and may not possibly be direct from the source for all stakeholders. Schaar \& Sherry (2010) stressed that the different needs of the airport stakeholders may not necessarily be under the airport management's control.

The klia2 terminal was commissioned in May 2014 replacing the Low Cost Carrier Terminal (LCCT) of the KL International Airport, which has been operating since March 2006. The project received extensive media coverage from its inception to its operational days due to criticism from its main operating airline towards the project and the project owner which is also the airport operator. The Public Accounts Committee (PAC) and the Auditor General (AG) office were directed to audit the project despite the fact that it was privately funded by the airport operator, Malaysia Airports Holdings Berhad (MAHB) (AG to audit klia2, 2015).

\section{Stakeholder theory}

Freeman (1984) developed the stakeholder theory where it assessed the role of actors in the firm's internal and external environment regarding managing the business in the turbulent times of the 21st Century. It is a theory of organisational management and ethics, in the field of strategic management. The goal of the stakeholder approach is for firms to look for a fit between both the company and its stakeholders' interests to maximise firms' performance. Management of a firm needs to ensure that they can find a healthy balance in its relationship with its various stakeholders. The stakeholder theory is viewed as either a complementary or an opposite to the Theories of the Firm; where a company's purpose is defined as 'to maximise shareholders wealth'. The Stakeholder theory suggests that in maximising shareholders' wealth, the company should take into consideration its other stakeholders' interest as well. Dohnalová \& Zimola (2014) insisted that stakeholder relationship management as vital to increasing a company's competitive advantage.

The theory is further developed, discussed and defined from various perspectives and angle (Freeman et al., 2010). Stieb (2009) insisted that criticism of Freeman's Stakeholder theory be inevitable, as it is eminent and is a very famous theory of business management that came out from a philosophical school of thinking. He was also concerned whether the stakeholder approach will improve any of the problems it was trying to address. Stakeholders may eventually make claims against firms which in turn affect the company's sustainability. In his opinion, there are serious repercussions to any company if the decision-making power is suggested to shift from the shareholders to the stakeholders of a firm.

Stakeholder theory was established to resolve the problems related to business (trade) and value creation, and yet research on value creation itself from the stakeholder perspective is limited (Freeman et al., 2010). Similar to the theory itself, there is also the narrow and broad definition of stakeholder value creation. The narrow view emphasises on small groups of stakeholders such as end users or shareholders while another view covers a larger set of stakeholder groups. According to Argandona (2011), an economic optimum is achieved when maximisation of value happened to all stakeholders, in line with the emphasis on the broad view of stakeholder value creation. Fitrijanti (2015) offered to simplify and operationalise the value concept by exploring means to quantify stakeholder value. However, complexity will remain as maximisation of each stakeholder does not guarantee efficient and fair distribution of value to all. The concept of value goes beyond economic value, making it more realistic to maximise value for all stakeholders. The challenge for value creation in the context of stakeholder theory is to generate a universal value which everybody needs instead of competing for scarce resources. 


\section{Airport stakeholders and their goals}

Schaar \& Sherry (2010) conducted an analysis of the stakeholders for airports which consists of 15 stakeholder groups. The list of airport stakeholders groups is as follows:

Passengers

Organisations

Air Carriers (airlines)

General Aviation

Airport Organisation

Investors and bondholders

Concessionaires

Service Providers

Employees

Federal Government

Local Government

Communities affected by airport operations

Non-Government Organizations (NGO), such as environmental bodies

Parking operators and ground transportation providers

Airport Suppliers

Each stakeholder group has different goals and objectives for the airport. All the stakeholder groups are relevant to the klia2 project except for General Aviation (GA) since there are no GA movements at the klia2 terminal. The various goals of the different groups and types of airport stakeholders (Schaar \& Sherry, 2010) were compared with the analysis of stakeholder's goals from an enterprise perspective (Dohnalova \& Zimola, 2014).

Table 1. Analysis of Airport stakeholder's goals

\begin{tabular}{|c|c|c|}
\hline Stakeholder & $\begin{array}{l}\text { Enterprise Stakeholder's goal } \\
\text { (Dohnalova \& Zimola, 2014) }\end{array}$ & $\begin{array}{l}\text { Stakeholder's goals for the airport } \\
\text { (Schaar \& Sherry, 2010) }\end{array}$ \\
\hline Owners & $\begin{array}{l}\text { Profit } \\
\text { Growth in Enterprise value } \\
\text { Investments }\end{array}$ & $\begin{array}{l}\text { Profitability } \\
\text { Sustainability } \\
\text { Operational Efficiency } \\
\text { Security } \\
\text { Safety }\end{array}$ \\
\hline Managers & $\begin{array}{l}\text { Growth in productivity } \\
\text { Maximisation of turnover } \\
\text { Pay and managerial benefits }\end{array}$ & Growth \\
\hline Employees & $\begin{array}{l}\text { Wages and benefits } \\
\text { Working conditions } \\
\text { Professional growth and education }\end{array}$ & Secure jobs, wages and benefits \\
\hline Suppliers & $\begin{array}{l}\text { Stable sales } \\
\text { Timely fulfilment of commitments } \\
\text { Payment conditions }\end{array}$ & Maximise traffic volumes \\
\hline Customers & $\begin{array}{l}\text { Product Quality } \\
\text { Product Price } \\
\text { Service, Warranty conditions } \\
\end{array}$ & $\begin{array}{l}\text { Passengers: Operational Efficiency, access to low fares } \\
\text { Airlines: Operational Efficiency, Safety, Profitability }\end{array}$ \\
\hline
\end{tabular}

\section{Stakeholder management for construction projects}

Yang \& Shen (2014) and PMBOK (2013) covered the importance of stakeholder engagement in the project management field. Success and failure of a project are linked to interactions between project stakeholders. 
Stakeholder management is not a one-time process but should be done continuously throughout the whole project lifecycle. It is important to obtain a better perception of project success as well as the criteria that contribute to project success from different stakeholders' perspectives (Davis, 2014). The Project Management Body of Knowledge (PMBOK) Guide (2013) stated that the purpose of stakeholder management apart from the project team is to ensure that the project requirements addressed the overall stakeholders' needs and expectations, to ensure a successful outcome.

Stakeholder management for construction projects is still closely linked to the area of general and public management rather than technical management. Despite the importance of stakeholder management in construction projects stressed by scholars especially in the 21st Century (Davis, 2014), a widely used and systematic framework to manage project stakeholders is still lacking (Yang \& Shen, 2014). This gap leads to their research in developing a systematic framework for stakeholder management in the construction industry. Davis (2014) conducted a review of multiple stakeholder groups' perceptions of project success based on research gap that there is no agreement on success factors definition for a certain group of stakeholders. The stakeholders, based on their critical interests in construction projects, were categorised in the table below.

Table 2. Stakeholders for construction projects

\begin{tabular}{|c|c|c|}
\hline \multicolumn{2}{|c|}{ Davis (2014) } & \multirow{2}{*}{$\begin{array}{l}\text { Yang \& Shen (2014) } \\
\text { Stakeholders }\end{array}$} \\
\hline Stakeholder Groups & Stakeholders & \\
\hline Senior Management & $\begin{array}{l}\quad \text { Board, director, executive, executive } \\
\text { management, investor, project executive, } \\
\text { portfolio director, program director, owner, } \\
\text { senior management, sponsor, top } \\
\text { management, project sponsor }\end{array}$ & $\begin{array}{l}\text { Clients } \\
\text { Financer/Sponsor Suppliers } \\
\text { Contractors } \\
\text { Consultants } \\
\text { End Users } \\
\text { Communities \& Public }\end{array}$ \\
\hline Project Core Team & $\begin{array}{l}\text { Engineer, other organisational } \\
\text { involvement (e.g. business departments), } \\
\text { project leader, project manager, project } \\
\text { personnel, project team leader, project } \\
\text { team, team members }\end{array}$ & $\begin{array}{l}\text { Government / District Council } \\
\text { Environmental Interest Group } \\
\text { Special Interest Group } \\
\text { Media } \\
\text { Competitors }\end{array}$ \\
\hline Project Recipient & $\begin{array}{l}\text { Client, consumer, customer, end users, } \\
\text { users }\end{array}$ & \\
\hline
\end{tabular}

\section{Stakeholders for the klia2 airport terminal project}

An identification of the klia2 Airport Terminal Project stakeholders was mapped based on the stakeholders groups from the research works of Stakeholder theory (Freeman, 1984), Airport stakeholder analysis (Schaar \& Sherry, 2010) and Construction stakeholders (Yang \& Shen, 2014).

Internal and external stakeholder groups of the klia2 project were identified, following the stakeholder groups as listed in the above research. The definition of internal stakeholders refers to parties belonging directly to the organisation while externals are outside the organisation which in this case is MAHB. According to the PMBOK Guide (2013), project stakeholders are defined as 'all members of the project team as well as all interested entities that are internal or external to the organisation'. The purpose of identifying project stakeholders apart from the project team is to ensure that the project requirements address the overall stakeholders' needs and expectations, towards ensuring a successful project outcome. The PMBOK Guide (2013) also mentioned operational stakeholders and is defined as 'stakeholders who perform and conduct business operations related to the project'. In the context of this research, the operational stakeholders are categorised as the operational and end users of the klia2 terminal, which consists of the following stakeholder groups: 
Airport service providers

Concessionaires

Hotel operators

Public transport operators

Special interest groups

Customs, Immigration, Quarantine, Police (Government Agencies operating at the airport terminal)

By elimination process, the project stakeholders are listed from the remaining stakeholder groups and can be listed as follows:

Airport organisation

Airport owners/shareholders

Appointed contractors

Appointed consultants

Local Government

Federal Government

Utility companies

Table 3. Identification of klia2 airport terminal stakeholders

\begin{tabular}{llll}
\hline $\begin{array}{l}\text { Stakeholder theory } \\
\text { (Freeman, 1984) }\end{array}$ & $\begin{array}{l}\text { Stakeholder for construction } \\
\text { projects (Yang \& Shen, 2014) }\end{array}$ & $\begin{array}{c}\text { Airport stakeholders } \\
\text { (Schaar \& Sherry, } \\
2010)\end{array}$ & klia2 stakeholders \\
\hline INTERNAL STAKEHOLDERS & - & Airport Employees & klia2 Employees \\
\hline $\begin{array}{l}\text { Employees } \\
\text { Unions }\end{array}$ & - & - & - \\
& Client & Airport Organisation & $\begin{array}{c}\text { Relevant MAHB Internal } \\
\text { Departments and subsidiaries }\end{array}$ \\
Owners & - & Airport Owners/ & MAHB Board of Directors \\
Financial Community & Financers/Sponsor & - & Majeholders \\
- & - & - & Minority Shareholders
\end{tabular}

EXTERNAL STAKEHOLDERS

\begin{tabular}{|c|c|c|c|}
\hline Suppliers & Suppliers & Organization/ Suppliers/ & Concessionaires (Retail, Hotel) \\
\hline- & Contractors & $\begin{array}{l}\text { Vendors/ } \\
\text { Concessionaires }\end{array}$ & Appointed Contractors \\
\hline \multirow[t]{2}{*}{-} & Consultants & - & Appointed Consultants \\
\hline & Utilities & - & $\begin{array}{l}\text { Utility Companies (TNEC, TNB, } \\
\text { Water) }\end{array}$ \\
\hline- & Communities \& Public & Local Communities & Communities \\
\hline Customers & End Users & Passengers & Passengers \\
\hline- & - & $\begin{array}{l}\text { Airport Service } \\
\text { Providers }\end{array}$ & Fuel Suppliers, Ground Handlers \\
\hline
\end{tabular}




\begin{tabular}{|c|c|c|c|}
\hline \multirow[b]{2}{*}{ - } & & Airlines & Airlines \\
\hline & - & $\begin{array}{l}\text { Public Transport \& } \\
\text { Car Park Operator }\end{array}$ & $\begin{array}{l}\text { Car Park, Bus \& Taxi Operator } \\
\text { Express Rail Link (ERL) }\end{array}$ \\
\hline $\begin{array}{l}\text { Customer Advocate } \\
\text { Groups }\end{array}$ & - & - & - \\
\hline \multirow[t]{3}{*}{ Government } & $\begin{array}{l}\text { Government/ } \\
\text { District Council } \\
\text { - }\end{array}$ & Local Government & $\begin{array}{l}\text { Local Council and Authorities } \\
\text { (Majlis Perbandaran Sepang, } \\
\text { Jabatan Bomba dan Penyelamat } \\
\text { Malaysia) }\end{array}$ \\
\hline & & Federal Government & $\begin{array}{l}\text { Ministry of Transport } \\
\text { Ministry of Finance } \\
\text { Ministry of Home Affairs } \\
\text { Department of Civil Aviation }\end{array}$ \\
\hline & & & $\begin{array}{l}\text { Customs, Immigration, Quarantine, } \\
\text { Health (CIQ) / Police }\end{array}$ \\
\hline Activist Group & Environmental Group & NGOs & Groups for People with Reduced \\
\hline Trade Associations & Special Interest Groups & - & Mobility \\
\hline Political Groups & - & - & - \\
\hline - & Media & - & - \\
\hline Competitors & Competitors & - & - \\
\hline
\end{tabular}

\section{Stakeholders' perception of the klia2 Airport Terminal Project}

The klia2 airport terminal started its construction in 2010 and was commissioned and used by the public since 2nd May 2014. It was the first purposely built airport terminal for low-cost airlines with the capacity to handle up to 45 million of annual passengers' throughput. MAHB funded the project as part of the National Economic Stimulus Package where private sectors contributed to the employment opportunities during the economic slowdown in the year 2009. MAHB raised funds to support the development of the klia2 terminal and support facilities through its 5tranche Senior Sukuk programme (MAHB, 2014). The klia2 airport terminal project received huge coverage during construction and after the opening of the facilities partly due to criticism from its main stakeholders such as the major airline operating at the terminal as well as passengers. However, the terminal was commissioned successfully on its opening day without any technical glitches, demarcating a successful operational readiness on the airport operator and its stakeholders' side. Many airports around the world faced huge problems during their opening day despite vigorous training and trials conducted. Davis (2014) discussed that despite the success of London Heathrow International Airport Terminal 5 project, the hiccups during commissioning of the terminal were perceived by the public and its customers as a project failure despite the ability of the project to be completed on time and according to budget (Brady \& Davies, 2010).

Airport stakeholders come from a variety of backgrounds and different nature of businesses and, therefore, various organisational goals and objectives (Schaar \& Sherry, 2010). Johansen et al. (2014) had similar views for project stakeholders and opined that it is almost impossible to get all stakeholders of a project involved and consulted at all times and highlight the need to make some generalisation for some stakeholders and situations. During an airport terminal development project, the project team will consult majority of the airport stakeholders and will capture their requirements for the project. The project team members may or may not necessary be the same team who eventually becomes the end users of the airport terminal.

Airport terminal design requires the consideration of passenger experience. Recent research has linked the profitability of an airport organisation with passenger satisfaction via the 'passenger experience concept'. Although 286 
passengers is an important stakeholder group of an airport terminal, formal and direct feedback from passengers is seldom taken into consideration when designing or developing an airport terminal. Airport terminal design has been challenged to produce outcomes beyond the purely functional and aesthetics spectacular by seeking opportunities to create a memorable experience and forge the relationship with passengers (Harrison et al., 2012). From a public transport services perspective, the essential elements that affect customer satisfaction are safety, followed by accessibility, reliability, fares, communication and experience (Kamaruddin et al., 2012). Aspects of accessibility to the persons with disabilities should not be neglected as Hussin \& Yaacob (2013) concluded it as lacking in the current public transportation system in Malaysia.

\section{Methodology - Measuring Stakeholders Satisfaction}

According to Turner \& Zolin (2012), the project managers' perception of customer, end users and operators' satisfaction are mainly related to the project specifications. The satisfaction aspect is true for various implications of a project such as a project output, outcome and impact. Therefore, it was suggested that satisfaction towards project specification may be used by project stakeholders to predict the customers, end users and operators' satisfaction. This opinion is in line with research by Bezerra \& Gomes (2015) who used the airport facilities and services as the service quality dimension that predicts the overall satisfaction of airport passengers. The service quality dimensions used by Bezerra \& Gomes (2015) were consistent with the industry best practices such as the Airport Service Quality (ASQ) survey for measuring airport passengers' satisfaction.

Customer satisfaction is vital for all types of businesses. Elements of customers' satisfaction get even more complex for service industries as it involves many aspects of the services as well as managing the customer's expectation. Furthermore, it relates to the intangible items unlike a physical product (Bezerra \& Gomes, 2015). Customers for an airport include both organisations and individuals. Ultimately, the main customers at the airport are the passengers. Various studies have looked into the factors which enhance or distract passenger's satisfaction (Bogicevic et al., 2013). They also discussed that many studies have started to focus on delighting the passengers and not merely satisfying them.

It is the right time to measure the outcome of the project from the stakeholders' perspectives especially the end users since it has been almost two years after the commissioning of the klia2 terminal. Finch (2003) conducted a post project evaluation using the Project Implementation Profile (PIP) to measure the project outcome of an information system project from both project team and the end user's perspectives. The (PIP) has been used to measure project performance from various project stakeholders' perspective. Therefore, it is proposed as a suitable instrument for this research to measure satisfaction for organisations which are the stakeholders of the project. However, there is very limited information whether the instrument has been used against end users of the project other than the clients and the project team members, as suggested by Rosacker et al. (2010). The instrument has mainly been used against project managers and technical personnel and professionals involved in project management (Alagba, 2013; Rosacker et al., 2010; Finch, 2003). As for passengers whom are the ultimate end users of the terminal, their satisfaction towards the service quality dimensions of the airport terminal facilities could be measured to reflect their overall satisfaction of the terminal (Bezerra \& Gomes, 2015). The main statistical tool proposed to analyse the factors affecting stakeholders' satisfaction is multiple linear regression analysis.

\section{Conclusion}

An organisation often mirrors their stakeholders' needs and requirements via their internal departments and divisions. Various departments in the organization exist to handle issues related to customers' satisfaction, investors' relations, airlines relations, authorities and regulatory requirements. For an airport terminal project, the stakeholders are a large group of organisations and individuals. During the project implementation, the project stakeholders which consist of both internal and external stakeholders would be required to collaborate to mirror the need for the operational stakeholders which are the operators and end users of the terminal. The main challenge would be whether the project stakeholders accurately emulate the operational stakeholders' needs and whether the value 
created by the project is relevant to all stakeholders. Based on the literature reviews, projects' outcome have been assessed mainly through the project managers' perspective and only recently through the project owners' and selected stakeholders' perspectives. The gap identified from literature stated that the satisfaction of project outcome was rarely examined from an overall stakeholders' perspective. Therefore, there is a need to measure the perception of the project outcome for all stakeholders for the klia2 project and obtain the collective perspectives of the various stakeholders. Although it may not be possible to achieve consensus neither would it be expected to obtain high satisfaction results from majority of the stakeholders, it is still worthwhile to analyse the results for the benefit of future projects.

\section{Acknowledgements}

Special thanks to the Ministry of Higher Education of Malaysia, Malaysia Airports Holdings Berhad and Universiti Teknologi MARA and all reviewers for their reviews and comments on this paper.

\section{References}

AG to audit klia2. (2015, May 23). New Straits Times (Malaysia)

Argandoña, A. (2011). Stakeholder theory and value creation, Working Paper, WP-922.

Bezerra, G.C.L. \& Gomes, C.F. (2015). The effects of service quality dimensions and passengers characteristics on passenger's overall satisfaction with an airport. Journal of Air Transport Management, 44 - 45, 77 - 81.

Bogicevic, V., Yang, W., Bilgihan, A. \& Bujisic, M. (2013), Airport service quality drivers of passenger satisfaction. Tourism Review, 68(4), 3 - 18.

Brady, T., \& Davies, A. (2010). From hero to hubris - Reconsidering the project management of Heathrow's Terminal 5. International Journal of Project Management, 28(2), 151-157.

Davis, K. (2014). Different stakeholder groups and their perceptions of project success. International Journal of Project Management, 32(2), 189201.

Dohnalová, Z., \& Zimola, B. (2014). Corporate Stakeholder Management. Procedia - Social and Behavioral Sciences, 110, 879-886.

Fageha, M. K., \& Aibinu, A. a. (2013). Managing Project Scope Definition to Improve Stakeholders' Participation and Enhance Project Outcome. Procedia - Social and Behavioral Sciences, 74, 154-164.

Finch, P. (2003). Applying Slevin-Pinto Project Implementation Profile to an Information Systems Project. Project Management Journal, 34(3), 3239.

Fitrijanti, T. (2015). Index of the Company's Stakeholders Welfare. Procedia - Social and Behavioral Sciences, 211(September), $1023-1027$.

Freeman, R.E, Harrison, J.S., Wicks, A.C, Parmar, B. \& Simone de Colle. (2010). Stakeholder Theory: The State of the Art. New York. Cambridge University Press.

Freeman, R.E (1984). Strategic Management: A Stakeholder Approach. Boston. Pitman Publishing Inc.

Harrison, A., Popovic, V., Kraal, B. J., \& Kleinschmidt, T. (2012). Challenges in passenger terminal design : A conceptual model of passenger experience. Proceedings of the Design Research Society, 344-356.

Hussein, H., \& Yaacob, N. M. (2013). Malaysian perspective on the development of accessible design, Asian Journal of Environment-Behaviour Studies, 4(12), 101-116.

Johansen, A., Eik-Andresen, P., \& Ekambaram, A. (2014). Stakeholder Benefit Assessment - Project Success through Management of Stakeholders. Procedia - Social and Behavioral Sciences, 119(1877), 581-590.

Kamaruddin, R., Osman, I., Anizaliana, C., \& Pei, C. (2012). Customer expectations and its relationship towards public transport in Klang Valley. Journal of Asian Behavioural Studies, 2, 10. 
Key, S. (1999). Toward a new theory of the firm: a critique of stakeholder "theory." Management Decision, 37(4), 317-328.

Kivits, R. A. (2011). Multi-dimensional stakeholder analysis : a methodology applied to Australian capital city airports, International Journal of Multiple Research Approaches. 5(3), 318 - 333.

Prime minister launches world's largest purpose built terminal - klia2 (2014, June 24). http://www.malaysiaairports.com.my (Retrieved on $8^{\text {th }}$ February 2016)

Project Management Institute. (2013). A guide to project management body of knowledge (PMBOK guide). Newton Square, Pa: Project Management Institute

Rosacker, K. M., Zuckweiler, K. M., \& Buelow, J. R. (2010). An empirical evaluation of hospital project implementation success. Academy of Health Care Management Journal VO - 6, 6(1), 37.

Schaar, D. \& Sherry. L. (2010). Analysis of Airport Stakeholders, Integrated Communications Navigation and Surveillance Conference (ICNS), J4 $1-17$.

Sözüer, M., \& Spang, K. (2014). The Importance of Project Management in the Planning Process of Transport Infrastructure Projects in Germany. Procedia - Social and Behavioral Sciences, 119(0), 601-610.

Stieb, J. A. (2009). Assessing Freeman's stakeholder theory. Journal of Business Ethics. 87, 401-414.

Toor, S.-R. \& Ogunlana, S. O. (2009). Construction professionals' perception of critical success factors for large-scale construction projects. Construction Innovation: Information, Process, Management, 9(2), 149-167.

Turner, R. \& Zolin, R. (2012). Forecasting success on large projects: developing reliable scales to predict multiple perspectives by multiple stakeholders over multiple time frames, Project Management Journal, 43(5), 87 - 99.

Yang R.J. \& Shen, G.Q.P. (2014). Framework for stakeholder management in construction projects. Journal of Management in Engineering, 31(4), 1-14. 